\title{
Legal Mechanisms on Waste Control and Responsibility to Protect: A Comparative Perspective
}

\author{
Kola O. Odeku \\ Faculty of Management and Law, University of Limpopo, Turfloop, South Africa
}

\section{Doi:10.5901/mjss.2014.v5n23p1498}

\begin{abstract}
Dumping of waste is one of the harmful activities impacting negatively on the environment. While it may be impossible to stop the dumping of waste by humans in entirety, it is possible to control and contain the act of dumping of waste through appropriate legal mechanisms put in place for such purpose. It is the right of everyone to seek an environment that is clean and not harmful and various environmental regulations in several countries recognise this. The paper looks at waste control from the perspectives of South Africa, India and the United Kingdom and analyses them in order to draw insightful lessons on how best to control waste.
\end{abstract}

Keywords: Waste, Dumping, Environment, Regulations, Comparison, Responsibility, Rights

\section{Introduction}

Section 24 of the Constitution of South Africa Act 108 of 1996 provides for the right to clean environment. It states that everyone has the right to an environment that is not harmful to their well-being and that the environment must be protected for the benefit of the present and future generations. Control and management of waste are envisaged by section 24 of the constitution (Du Plessis, 2011). Harmful wastes dumped in the environment are sources of environmental hazards and as such, they deprive people of the right to enjoy an environment that is not harmful to health and survival (Shelton, 2006). Therefore, control and management of waste become imperative in order to have a clean environment suitable to human health and the ecosystem (LaGrega, 2010). In South Africa, the issue of environment falls within the fundamental rights, apart from other legislation on waste, waste management is currently regulated by the National Environmental Management: Waste Act 59 of 2008 (NEMWA). However, in India, the right to an environment not harmful to the well-being of the people is not a fundamental right; (Boyce, 2000) it is one of the directive principles of the state policy and mere guidelines (Razzaque, 2002). By virtue of Article $48 \mathrm{~A}$ of the Constitution of India, the state is expected to take steps to protect and improve the environment; however, the citizens have more responsibility to protect the environment than the state. This is articulated in article $51 \mathrm{~A}(\mathrm{~g})$ which places a fundamental duty on every citizen of India to protect and improve the natural environment. In the United Kingdom (UK), responsibility is shared by the local authority and the county. The local authority is responsible for the collection of waste while the county council is responsible for the disposal of such waste (Petts, 2001).

In South Africa, waste is defined in terms of section 1 of NEMWA as, any substance whether or not that substance can be reduced, recycled and recovered:

a) That is surplus, unwanted, rejected, discarded, abandoned or disposed of.

b) Which the generator has no further use of, for the purpose of production

c) That must be treated or disposed of

d) That is identified as waste by the minister, by notice in the Gazette and includes waste generated by mining, medical and other sector.

Section 1 of the Act makes ample provision for waste control mechanisms such as collection and handling, reducing, recycling, reusing, recovery, treatment and disposal of waste.

\section{Control and Management of Waste}

It is incumbent on the State to control and manage waste through appropriate measures in order to keep the environment clean and suitable for living (Raum-Degreve, 1987). South Africa have protected rights under the constitution in terms of section 24 ( Fuggle et al. 2009) which addresses the issues of clean environment. Section 3 of the Waste Act reinforces 
section 24 and stipulates that the State has the general duty to ensure that section 24 of the Constitution is complied with. Consequent to this, the State must put in place uniform measures that seek to reduce the amount of waste being generated, ensure that waste is re-used, recycled and recovered in an environmentally sound manner before being treated and disposed of. The NEMWA further places a duty on the Minister to ensure that a national waste management strategy is implemented, which must include objectives, plans, guidelines, systems and procedures relating to; the protection of the environment the re-use, recycling, recovery, treatment disposal, use, control and management of waste. Mechanisms, systems and procedures giving effect to the State's obligations in terms of international agreements ensures to achieve co-operative governance in waste management.

The minister must also set national standards, which among others will address the following:

- Planning for and provision of waste management services.

- Minimisation, re-use, recycling and recovery of waste.

- Regionalisation of waste management services (Section 7 (2) of Act 59 of 2008).

NEMWA places a duty on the relevant member of the Members of the Executive council (MEC) to ensure that the national waste management strategies are implemented, the MEC is also granted the powers to set provincial norms and standards which do not conflict with the national norms and standards. One of the purposes of the provincial norms and standards is the regionalisation of waste management services within the province.

It is the municipality that has the duty to ensure that waste management services are provided and delivered (Miraftab, 2004). Schedule 5 part B of the Constitution stipulates that the local government (Municipality) is placed with the duty of refuse removal, refuse dump and solid waste disposal. Section 9 of NEMWA stipulates that the municipality must exercise its executive authority to deliver waste management services including waste removal, waste storage and waste disposal. However, in the exercise of such authority, the municipality must not act in conflict with the national and provincial norms, ensuring that everyone has access to the waste management services at an affordable price. It is therefore, the duty of the municipality, to ensure that waste is removed. as they are responsible for the "day to day" management of waste. The national or provincial government may however interfere if these duties are not being complied with accordingly or correctly.

In order to give effect to this duty, a number of provinces have implemented by-laws which deal with waste management in their respective provinces. For example in Limpopo, the Limpopo Environmental Management Act 7 of 2003 is in place. Section 92 of this act stipulates that the MEC is obliged to make regulation pertaining to waste management in that particular province. It must be indicated that such by- laws must not deviate from the national norms and standards or the provision of superior legislations relating to environmental law.

To some extent, in Limpopo, the municipalities are playing their roles in ensuring that waste management is dealt with, for example in its Integrated Development Plan (IDP) budget (Capricorn District Municipality Budget 2010/2011), the Capricorn District Municipality indicates the various methods it uses to deals with waste (Raophala, 2013). For example, it indicates that it is implementing air quality monitoring control, it has environmental management plans in place, it is involved in the training education and awareness relating to environmental management and it has set down a budget of about R27, 000, 000 for acquisition of waste equipment and construction of landfills (Maluleke, 2014). In 2011/2012 (Capricorn District Municipality Original Budget 2011/2012), the Capricorn District Municipality indicated the need for proper waste management within the district. It was noted that one of the key areas of the IDP is waste management and that there is a need to complete the landfills construction site in Molemole, Blouberg, Lepelle-Nkupi and Aganang Municipalities. An amount of R21, 3000, 000 was set aside for the completion of these constructions. An amount of R8, 6000,000 was also set aside to implement programmes to monitor air quality, environmental training projects, running of landfill sites, launching programmes to clean cemeteries and community based waste collection (Capricorn Budget, 2009).

At page 4, the municipality asserts that:

- The district is Implementing the Air Quality monitoring programme

- Establishment of landfill site in Blouberg and Lepelle-Nkumpi is on progress

- Environmental management plans are available

- It is also involved in the training, education and awareness of communities around environmental management

- The challenge faced by CDM is with regard to environmental management matters and the unavailability of the technical capacity to manage the sites at local municipalities.

- The budget of R14, 8m has been made available for acquisition of waste equipment and the construction of additional landfill sites at Aganang and Molemole." (Capricorn Budget 2009). 


\section{Comparative Perspectives}

It is pertinent to point out that the right to an environment that is not harmful to people's well-being is not a fundamental right in India; (Atapattu 2002) but one of the directive principles of the state policy. These directive principles of state policy are mere guidelines for framing law by the government. Article $48 \mathrm{~A}$ of the Constitution of India stipulates that the state shall endeavour to protect and improve the environment and to safeguard the forest and wildlife of the country, whereas article $51 \mathrm{~A}(\mathrm{~g})$ places a fundamental duty on every citizen of India to protect and improve the natural environment, including forests, lakes, rivers and wildlife and to have compassion for living creatures. This is slightly different from the South African environmental law as the duty of the state to ensure that the environment is free from harm is clearly defined as one of the fundamental rights of everyone in the Republic (Lee, 2000).

However, there are a number of laws in India which deal with waste management. Such laws include the following: the Municipal Solid Waste (Management and Handling) Rules, 2000. Section 2 of the Rules stipulates that Municipal solid waste include commercial and residential wastes generated in municipal or notified areas in either slid or semi-solid form excluding industrial hazardous wastes, but includes treated bio-medical waste. Rule 4 dictates that every municipal authority is responsible to implement rules relating to waste management and any infrastructure for the collection, storage, segregation, transportation, processing and disposal of municipal solid waste. This situation is similar to the South African position whereby municipalities are required to deal with refuse collection and disposal thereof. It also requires the municipality or operator to get permission before setting up a waste processing and disposal facility. In this regard, the situation is not that different from the South African law, as it requires any person who wishes to operate a facility meant to deal with the disposal or treatment of waste to obtain a permit from the relevant minister.

The rule also dictates that municipal authorities are bound to establish and maintain storage facilities so that they do not create unhygienic and insanitary conditions. These storage facilities shall be created keeping in view the quantity of waste generation and accessibility to users. It should not be open and it should be aesthetically acceptable and user friendly.

The Indian waste management situation is not that different to the system used in South Africa, however due to the intense rate of urbanisation in India, the burden to manage waste is much more intense than that of South Africa. For example, the city of Delhi is the most populated cities in India and one of the dirtiest in the world. However, despite the fact that India is one of the most rapidly urbanised areas in the world, its major challenge is that its policies on waste management are not that well developed and recycling and reusing are not used as the primary manner of waste management (Asnani and Zurbrugg, 2007). Lack of awareness or sensitivity by the public towards the need to a clean environment and the importance of reusing and recycling is one thing that South Africa and India have in common.

In England and Wales, the local authority is responsible for the collection of waste, whereas the county council is responsible for the disposal of such waste ( Tonglet et al. 2004). In Scotland, the Scottish Environment Protection Agency is the enforcing authority on all sorts of waste. The management of waste is regulated by the E.C directive E.C Directive 2006/12/EC On Waste. This directive defines waste as any substance or object in the categories set out in Annex I which the holder discards or intends or is required to discard. Article 3 of the directive indicates that Member States shall take appropriate measures to encourage:

(a) First, the prevention or reduction of waste production and its harmfulness, in particular by:

(i) The development of clean technologies more sparing in their use of natural resources;

(ii) The technical development and marketing of products designed so as to make no contribution or to make the smallest possible contribution, by the nature of their manufacture, use or disposal, to increasing the amount or harmfulness of waste and pollution hazards;

(iii) The development of appropriate techniques for the final disposal of dangerous substances contained in waste destined for recovery.

In order to ensure that above mentioned are properly implemented or taken into consideration, policies such as the Waste Strategy of England 2007 have played a significant role. This policy is responsible for placing the United Kingdom above most countries in term of how they deal with waste (Barr, 2007). The policy is constructed in such a manner that encourages businesses to minimise the production of waste. The policy recognises that the major challenge with regards to waste management is the lack of economic incentives for businesses and individuals to reduce waste (Deutz et al. 2010). In order to overcome this challenge, the policy indicates that hazardous wastes that are disposed to landfills are subjected to what is known as Landfill taxes, this entails that the more hazardous waste is disposed by a business to landfill, the more the amount of tax payable (Davies, 2007).

The UK, as a signatory to the Basel Convention is in support of the need to train consult, disseminate information, and create awareness and technological transfers on matters relating to the environmentally sound management of 
waste (Kempel, 1999). The policy also provides that any person who is participating in industrial productions which might cause harm to the environment is obliged to minimise pollution from various industrial sources and must obtain a permit containing environmental requirements which include the following:

- The use of the best available techniques of waste management

- The polluter pays principle.

From the above policy statements, it is clear that the UK goes beyond the simple principle of polluter must pay, but engage in activities to ensure that waste is managed even before it is produced (Chapman and McCombie, 2003). This situation is a bit different to the South African whereby, the principle of polluter must pay is given more emphasis than other forms of principles on environmental and waste management.

Another factor which places the UK at the forefront with regards to waste management as opposed to South Africa is that, it has a more comprehensive data collection system which indicates who is polluting and how much is the amount of the pollution (Dlamini, 2008). This data is published on an annual basis and is available to the public. This system is likely to reduce the amount of pollution being produced by a company.

The situation in the United Kingdom is a bit similar to that of South Africa, however, the United Kingdom's progress with regards to the activities of waste management, like recycling seems to be more advanced than that of South Africa and India. Due to its effective policies, the UK has managed to increase the percentage of recycling to 27 in 2005-06, recycling of packaging waste from $27 \%$ to $56 \%$ and less waste is being disposed to landfills on a yearly basis (Aidoo, 2005). So far, the comparative analysis show that people in the UK seem to be more sensitised to the prevention, recycling and reusing of waste than their South African and Indian counterparts (Chakrabarty, 2013).

\section{Managing and Dealing with Waste}

There should be a concerted effort on how to deal with hazardous waste generation for purposes of management since waste generation cannot be avoided (LaGrega, 2010). However, literature on waste control and management recognised that waste can be minimised, re-used, recycled, recovered or treated and as a measure of last resort, be disposed of ( Arena and Di Gregorio, 2014).

\subsection{Waste Minimisation}

Waste minimisation is defined as the application of a systematic approach to reduce waste at sources; this means preventing or reducing the generation of waste (Halim and Srinivasan, 2002). In waste management, prevention of waste is usually preferred to treating waste already generated ( Morrissey and Browne, 2004). This process of minimisation can be done by deploying various methods for reducing the generation of waste at source and improving efficiency, thereby reducing harm to the environment (Asnani, and Zurbrugg, 2007).

This process has been successfully deployed and used by a number of companies and they have recorded major financial benefits due to the reduction of waste. For example, the BMW's Rosslyn facilities, after the implementation of this method of dealing with waste management, the company reported a reduction in water usage of more than $80 \%$ per unit produced (Pandey, 2008). The water was enough to supply 765,040 household with water for a month. The company did not only save money on its water bill, but also used water in a sustainable manner, thereby aiding the environment (National Waste Management Strategy Implementation South Africa: Recycling 2005 pg. 15). Therefore, minimising of waste may result in saving money and the environment at the same time.

\subsection{Recycling and re-using waste}

One of the ways of effectively managing waste is through the recycling or re-using of waste ( Tonglet et al. 2004). This entails that waste is used in an alternative, useful manner that will ultimately result in waste minimisation (Phale, 2012). One of the effective ways in which waste can be recycled or reused is through the process called Industrial Waste Exchange (Cohen-Rosentha, 2004). This process is an internationally recognised waste recycling process (Nemerow, 1995). It is a method of recycling and reusing industrial waste, for example to provide for alternative energy ( Jenck et al. 2004). Waste Minimisation Situation Baseline Analysis Report is a process whereby waste from industries or any form of waste is reused or recycled to form a valuable product. The process links industrial waste generator with waste recyclers and companies that can use waste as a raw material input for their products (Vergara and Tchobanoglous, 2012).

In South Africa, the Industrial Waste Exchange was introduced in 2000, by the Waste Management Department of the cape metropolitan municipality. There is no legation in South Africa that tackles recycling and re-using specifically. 
Recycling also includes the recovery of waste as both can be diverted from the concept of waste and used turned into an economically beneficial product.

The recycling, reduction, re-using and recovery of waste is provided for by section 17 of the Waste Act, which provides that any person can carry out activities relating to these concepts and that before they can be carried out the person must ensure that:

- The processes uses less natural resources that the disposal of the waste

- It is less harmful to the environment than the disposal of such waste.

\subsection{Treatment of waste}

Treatment of waste implies curtailing and containing impact of hazardous waste on the environment (Lee et al. 1994). Waste treatment is initiated after the waste has already been generated, but is detoxified so that once discharged into the environment, it can have less harmful impact or effects (Oller et al. 2007).

\subsection{Disposal of waste}

Disposal of waste is when waste is discarded in a manner not harmful to the environment (LaGrega et al. 2010). This method is used as last resort of waste management in most countries (Cheremisinoff, 2003). It should however should be done responsibly otherwise, it will attract civil/criminal responsibilities ( Rebovich, 1992). Section 26 of the Waste Act prohibits anyone from discarding waste in or on any land, water body or at any facility unless authorised by law. The section further prohibits any person from discarding waste in a manner that is harmful to the environment.

\section{Conclusion}

South Africa classifies the issues of environment as protected rights and as such, the constitution places obligations on the state, to fulfil the right to a clean environment that is free from hazardous wastes and so on. Hence, this creates a clear mandate for waste control and management. India and the UK can learn lessons from this.

South Africa can absorb from the UK the methods of waste management on an individual basis, such as re-using recycling and so forth. Although, South Africa might not be the leading country with regard to waste management, it is better compared to India which for example does not recycle but relies mostly on disposal of waste, whereas, in South Africa disposal of waste is considered as a measure of last resort.

To forge a culture of an effective waste control and management, South Africa should improve its policies and laws on waste control in order to decrease the amount of dumping of hazardous substance known to be major contributor to health problems.

\section{References}

Aidoo R 2005. Waste management in offices: a case study of the Norfolk and Norwich University Hospital. From http://www.uea.ac.uk/ env/all/teaching/eiaams/pdf_dissertations/2005/Aidoo_Ruby.pdf. (Retrieved 12 June, 2014).

Arena U and Di Gregorio F 2014. A waste management planning based on substance flow analysis. Resources, Conservation and Recycling, 85: 54-66.

Asnani PU, Zurbrugg C 2007. Improving municipal solid waste management in India: A sourcebook for policymakers and practitioners. The International Bank for reconstruction and Development/The World Bank, Publication, Washington, USA.

Asnani PU, Zurbrugg C 2007. Improving municipal solid waste management in India: A sourcebook for policymakers and practitioners. The World bank, Washington, USA.

Atapattu S 2002. Right to a Healthy Life or the Right to Die Polluted: The Emergence of a Human Right to a Healthy Environment under International Law. Tulane Environmental Law Journal, 16: 65-73.

Barr S 2007. Factors Influencing Environmental Attitudes and Behaviors A UK Case Study of Household Waste Management. Environment and Behavior, 39(4): 435-473.

Boyce JK 2000. Let Them Eat Risk? Wealth, Rights and Disaster Vulnerability. Disasters, 24(3):

Capricorn Budget 2009. Final reviewed 2009/2010 idp/budget, capricorn district municipality, final reviewed 2009/2010 idp/budget capricorn district. from cdmunicipality.wsiefusion.net_literature_37740/... · DOC file. (Retrieved 26 August, 2014).

Chakrabarty DK 2013. Environmental and Social Sustainablity: Key Issues and Concerns. From http://rbidocs.rbi.org.in/rdocs /bulletin/ pdfs/04bsp_100513f.pdf. (Retrieved 12 July, 2014).

Chapman N, McCombie C 2003. Principles and standards for the disposal of long-lived radioactive wastes. Elsevier Science Ltd, Oxford, UK. 
Cheremisinoff NP 2003. Handbook of solid waste management and waste minimization technologies. Butterworth-Heinemann, Massachusetts, USA.

Cohen-Rosentha E 2004. Making sense out of industrial ecology: a framework for analysis and action. Journal of Cleaner Production. 12( 8-10):1111-1123.

Davies S 2007. Politics and markets: The case of UK municipal waste management. From http://newunionism.net/library/member\%20 contributions/. (Retrieved 25 November, 2014).

Deutz P, Neighbour G, McGuire M 2010. Sustainable Development. From http://onlinelibrary.wiley.com/doi/10.1002/sd.469/full. (Retrieved 2 August, 2014).

Dlamini TH 2008. An environmental liability and risk management approach to landfill groundwater quality monitoring in South Africa.http://wiredspace.wits.ac.za/handle/10539/4938. (Retrieved 2 November, 2013).

Du Plessis A 2011. South Africa's constitutional environmental right (generously) interpreted: what is in it for poverty? South African Journal on Human Rights, 27(2): 279-307.

Fuggle RF, Rabie MA, Strydom HA, King ND 2009. Environmental Management in South Africa. Cape Town, South Africa.

Halim I, Srinivasan R 2002. Systematic waste minimization in chemical processes. Industrial \& engineering chemistry Research, 41(2): 196-207.

Agterberg F, Droescher MJ 2004. Products and processes for a sustainable chemical industry: a review of achievements and prospects. From http://pubs.rsc.org/en/content/articlelanding/2004/gc/b406854h/unauth\#!divAbstract. (Retrieved 5 June, 2013).

Kempel W 1999. The negotiations on the Basel convention on the transboundary movement of hazardous wastes and their disposal: A national delegation perspective. From http://link.springer.com/. (Retrieved 2 November, 2014).

LaGrega MD, , Buckingham PL, Evans - JC 2010. Hazardous waste management.. Waveland Press, Illinois, USA.

LaGrega MD, Buckingham PL, Evans JC 2010. Hazardous waste management. Waveland Press, Illinois, USA.

Lee GF, Jones-Lee A, Lee GF 1994. Impact of municipal and industrial non-hazardous waste landfills on public health and the Environment: An overview. From http://www.gfredlee.com/Landfills/cal_risk.pdf. (Retrieved 5 May, 2013).

Lee J 2000. Underlying Legal Theory to Support a Well-Defined Human Right to a Healthy Environment as a Principle of Customary International Law. Columbia Journal of Environmental Law. 25:283-290.

Maluleke PH 2014. A review of solid waste management practices in Polokwane City. From http://uir.unisa.ac.za/handle/10500/13385. (Retrieved 16 August, 2014).

Miraftab F 2004. Neoliberalism and casualization of public sector services: the case of waste collection services in Cape Town, South Africa. International Journal of Urban and Regional Research, 28(4): 874-892.

Morrissey AJ, Browne J 2004. Waste management models and their application to sustainable waste management. Waste Management. 24(3): 297-308.

Nemerow NL 1995. Zero pollution for industry: Waste minimization through industrial complexes. John Wileys \& Sons, New York, USA.

Oller I, Malato S, Sánchez-Pérez JA, Maldonado MI, Gassó R 2007. Detoxification of wastewater containing five common pesticides by solar AOPs-biological coupled system. Catalysis Today, 29(1-2): 69-78.

Pandey AK 2008. Identification and assessment of cleaner production technologies and appropriate technology management strategies and methods in the South African vehicle. From http://www.repository.up.ac.za/handle/2263/30463. (Retrieved 21 April, 2013).

Petts J 2001. Evaluating the Effectiveness of Deliberative Processes: Waste Management Case-studies. Journal of Environmental Planning and Management, 44: 207-226.

Phale AR 2012. Environmental impact and waste management of used tyres in the RSA. From https://ujdigispace.uj.ac.za /handle/10210/7154. (Retrieved 22 June, 2014).

Raophala MH 2013. Municipal service delivery in Greater Tzaneen Local Municipality in Limpopo Province: a case of Lenyenye Township. From http://ul.netd.ac.za/bitstream/10386/1007/1/raophala_mh_2013.pdf. (Retrieved 5 March, 2013).

Raum-Degreve M 1987. Community policy concerning the management of dangerous waste. Research and Documentation Papers, Environment, Public Health and Consumer. From http://aei.pitt.edu. (Retrieved 1 August, 2013).

Razzaque J 2002. Human rights and the environment: the national experience in South Asia and Africa. From http://eprints.uwe.ac. uk/18403/1/Joint\%20UNEP\%20-\%20Razzaque.pdf. (Retrieved 15 March, 2013).

Rebovich DJ 1992. Dangerous ground: the world of hazardous waste crime. Transaction Publishers, New Jersey, USA.

Shelton, Dinah 2006. Human Rights and the Environment: What Specific Environmental Rights Have Been Recognized. Denver Journal of International Law \& Policy, 35: 129-134.

Tonglet M, Phillips PS, Read AD 2004. Using the Theory of Planned Behaviour to investigate the determinants of recycling behaviour: a case study from Brixworth, UK. Resources, Conservation and Recycling, 41(3): 191-214.

Vergara SE, Tchobanoglous G 2012. Municipal solid waste and the environment: a global perspective. Annual Review of Environment and Resources. 37: 277-309. 